\title{
Oxygen Isotopic Fingerprints on the Phosphorus Cycle Within the Subseafloor Biosphere
}

\author{
MINGYU ZHAO ${ }^{1}$, RUTH BLAKE ${ }^{2}$, NOAH J. \\ PLANAVSKY $^{2}$, DEB P JAISI ${ }^{3}$, YUHONG LIANG ${ }^{2}$, SAE \\ JUNG CHANG ${ }^{4}$ AND DEREN DOGRU ${ }^{2}$
}

${ }^{1}$ University of Leeds

${ }^{2}$ Yale University

${ }^{3}$ University of Delaware

${ }^{4}$ Korea Basic Science Institute, Seoul Center

Presenting Author: earmzh@leeds.ac.uk

The oxygen isotopic composition of phosphate holds important information on $\mathrm{P}$ cycling and microbial activity due to the distinct oxygen isotopic fractionations accompanying multiple $\mathrm{P}$ pathways and metabolic processes. Here we report the oxygen isotopic compositions $\left(\delta^{18} \mathrm{O}\right)$ of both dissolved inorganic phosphate (DIP) and sedimentary phosphate in deep-sea sediments to over $200 \mathrm{~m}$ depths at ODP Site 1230 . We have placed the results into a quantitative framework and found that the $\delta^{18} \mathrm{O}$ value of DIP $\left(\delta^{18} \mathrm{O}_{\mathrm{DIP}}\right)$ is mainly controlled by three pathways of P cycling at Site 1230: (1) release of DIP by enzymatic degradation of organic matter, (2) removal of DIP by the precipitation of authigenic apatite, and (3) enzyme-catalyzed $\mathrm{O}$-isotopic exchange between phosphate and water. In particular, there is a shift of $\delta^{18} \mathrm{O}_{\mathrm{DIP}}$ towards equilibrium around $140 \mathrm{~m}$ below seafloor, in parallel with a change in microbial communities. This suggests $\delta^{18} \mathrm{O}$ of phosphate as a potential proxy for microbial activities in the subseafloor deep biosphere. Our model simulations also suggest that the rate of O-isotopic exchange is correlated with the rate of organic matter decomposition, implying microbially and enzymatically controlled isotopic exchange. Lastly, bulk sediment $\delta^{18} \mathrm{O}_{\mathrm{P}}$ values as well as the abundance of each sediment phosphate phase (detrital apatite, authigenic apatite and Fe-bound phosphate) suggests that authigenic apatite and/or Fe-bound phosphate can record the $\delta^{18} \mathrm{O}$ value of porewater DIP during their formation. 